\title{
Control of Jointvetch (Aeschynomene spp.), Establishment and Productivity of Rice as a Function of [Imazapic + Imazapyr] Doses
}

\author{
G. Concenço ${ }^{1}$, A. Andres ${ }^{1}$, F. Schreiber ${ }^{2}$, I. S. Moisinho ${ }^{2} \&$ M. B. Martins ${ }^{2}$ \\ ${ }^{1}$ Embrapa Clima Temperado, Pelotas, RS, Brazil \\ ${ }^{2}$ Plant Health, Federal University of Pelotas, Pelotas, RS, Brazil \\ Correspondence: G. Concenço, Embrapa Clima Temperado, Rodovia BR-392, Km 78, $9^{\circ}$ Distrito, Monte Bonito, \\ Caixa Postal 403, CEP: 96010-971, Pelotas, RS, Brazil. E-mail: germani.concenco@embrapa.br
}

$\begin{array}{ll}\text { Received: December 21, } 2018 & \text { Accepted: February 11, 2018 } \quad \text { Online Published: March 15, } 2018 \\ \text { doi:10.5539/jas.v10n4p287 } & \text { URL: https://doi.org/10.5539/jas.v10n4p287 }\end{array}$

\begin{abstract}
We aimed with this work to evaluate the efficiency of the herbicide [imazapic + imazapyr] in the weed control, especially of the jointvetch, and its reflex in rice plant establishment and grain yield. A field study was conducted, where treatments were: control without herbicide application; Kifix ${ }^{\circledR} 140 \mathrm{~g} \mathrm{ha}^{-1}\left(24.5 \mathrm{ga}_{\mathrm{a} . \mathrm{i}} \mathrm{ha}^{-1}\right.$ imazapic $+73.5 \mathrm{~g}_{\mathrm{a} . \mathrm{i}}$. $\mathrm{ha}^{-1}$ imazapyr) and Kifix ${ }^{\circledR} 280 \mathrm{~g} \mathrm{ha}^{-1}\left(49 \mathrm{~g}_{\mathrm{a} . \mathrm{i} .} \mathrm{ha}^{-1}\right.$ imazapic $+147 \mathrm{~g}_{\mathrm{a} . \mathrm{i} .} \mathrm{ha}^{-1}$ imazapyr). We evaluated crop emergence up to 25 days after sowing, crop plant height 12 days after emergence (DAE), jointvetch plant density 31 and 62 DAE, jointvetch dry mass 62 DAE and general weed infestation 62 DAE. At the end of the crop cycle we evaluated grains per panicle, panicle and 1000 grain weight, panicle density and crop grain yield. There is a risk of $15 \%$ reduction in the establishment of Clearfield ${ }^{\circledR}$ rice plants when the maximum dose of the herbicide [imazapic + imazapyr] is applied pre-emergence, but under appropriate conditions, the crop development tends to compensate for this reduction in establishment. The herbicide [imazapic + imazapyr] is effective on jointvetch, but under high infestation conditions, as in the present study, a complementary herbicide application is required to achieve adequate control of jointvetch and avoid rice grain yield reduction due to competition.
\end{abstract}

Keywords: Kifix ${ }^{\circledR}$, Oryza sativa, emergence, infestation, Aeschynomene spp.

\section{Introduction}

Rice is one of the most important cereals produced in the world. It is cultivated mainly in paddy fields using a continuous flooding. In Brazil, Rio Grande do Sul (RS) and Santa Catarina (SC) States are the main producers, being responsible for approximately $80 \%$ of the national production, where the average productivity is 6,837 and $7,139 \mathrm{~kg} \mathrm{ha}^{-1}$, respectively (CONAB, 2017).

Paddy rice cropping fields in southern Brazil are generally highly productive, although yield averages are still lower than those achieved in areas that adopt recommended cropping practices such as experimental fields. One of the main reasons for yield reduction in this crop is related to unsatisfactory weed control (Galon et al., 2007; Agostinetto et al., 2008). The importance of weed infestation on rice grain yield has been increasing due to the adoption of minimum till and the low efficacy of non-selective herbicides against them.

Weedy rice and Echinochloa sp. are the most important weeds in paddy rice in RS and limit crop productivity due to their competitive ability and wide occurrence throughout the state (Agostinetto et al., 2001). Another weed commonly found in rice fields is the jointvetch (Aeschynomene rudis and A. denticulata), which impacts rice cultivation by reducing its grain yield, causing trouble to the harvesting operation, and affect seed/grain quality. In addition, jointvetch produces large amounts of seeds, which contributes to the increase of soil weed seed bank, interfering in subsequent crop cycles as well as in crops planted in succession to rice. It is a dicotyledonous that often requires herbicide applications specially directed to its control (Ferreira, 2007).

Currently, with the introduction of Clearfield ${ }^{\circledR}$ technology, herbicides belonging to the chemical group of imidazolinones are primarily used for weed control. These herbicides inhibit the Acetolactate Synthase enzyme (ALS) and are highly efficient. However, the repeated application of these herbicides at doses above the recommended, causes prolonged residual effect. In addition, the absence of mechanisms of action rotation over time in the same area increases the selection pressure (Vargas, 2017) and favors the appearance of resistant biotypes to imidazolinones. Thus, several biotypes of weedy rice have already been found to be resistant to 
ALS-inhibiting herbicides in Brazil (Heap, 2017).

In rice fields planted with Clearfield ${ }^{\circledR}$ rice varieties, there are frequent complaints that the herbicide [imazapic + imazapyr], associated to the technology, does not provide sufficient control of jointvetch. This situation is aggravated when the herbicide is applied post-emergence, when most jointvetch plants are taller, and some growers choose to use the maximum herbicide registration dose of [imazapic + imazapyr] with no clear information about the impact of this decision on Clearfield ${ }^{\circledR}$ rice establishment, or on the emergence of non-Clearfield ${ }^{\mathbb{B}}$ cultivars planted in succession.

Some studies report the potential damage of Clearfield-related herbicides, as imazethapyr, on non-Clearfield ${ }^{\circledR}$ rice varieties (Kraemer et al., 2009; Dornelles et al., 2010; Bundt et al., 2015; Ceolin et al., 2017), and other crops planted in succession to Clearfield rice (Alister \& Kogan, 2005; Pinto et al., 2009). In addition, some studies reported possible damages to Clearfield rice after application of Kifix (Sousa, 2010; Galon et al., 2012) but with no conclusive data.

Thus, we aimed to evaluate the efficiency of the herbicide [imazapic + imazapyr] in the weed control, especially of jointvetch, and its effects on plant establishment and rice grain yield.

\section{Method}

The study was installed in an experimental field at Embrapa Clima Temperado, Terras Baixas Station, Capão do Leão (RS), Brazil, geographic coordinates -31.8153 ; -52.4698 in randomized blocks design, with plots measuring $4 \times 18 \mathrm{~m}\left(72 \mathrm{~m}^{2}\right)$, and four replications.

The vegetation burndown prior to planting was done with $1440 \mathrm{~g}_{\text {a.e. }} \mathrm{ha}^{-1}$ of glyphosate, seven days before sowing the cultivar Guri INTA CL, on 11/09/2016, with row spacing of $0.17 \mathrm{~m}$. The base fertilization consisted of 300 $\mathrm{kg} \mathrm{ha}^{-1}$ of the formula N-P-K 5-25-25 applied to the planting row.

Treatments included: (T1) control without herbicide application; (T2) Kifix ${ }^{\circledR} 140 \mathrm{~g} \mathrm{ha}^{-1}\left(24.5 \mathrm{gaai}_{\mathrm{ai}} \mathrm{ha}^{-1}\right.$ imazapic + $73.5 \mathrm{~g}_{\text {a.i. }} \mathrm{ha}^{-1}$ imazapyr) and (T3) Kifix ${ }^{\circledR} 280 \mathrm{~g} \mathrm{ha}^{-1}\left(49 \mathrm{ga}_{\mathrm{a} . \mathrm{i}} \mathrm{ha}^{-1}\right.$ imazapic $+147 \mathrm{~g}_{\text {a.i. }} \mathrm{ha}^{-1}$ imazapyr). The application was carried out one day after planting (DAP), via precision equipment propelled by $\mathrm{CO}_{2}$, connected to a bar with six 110.02 nozzles spaced in $0.5 \mathrm{~m}$ and subjected to the necessary pressure to apply the equivalent to $150 \mathrm{~L} \mathrm{ha}^{-1}$ of herbicide solution.

Topdressing fertilization was done on two moments: beginning of tillering (12/09/2016) and a few days before panicle initiation (01/13/2017), each with $100 \mathrm{~kg} \mathrm{ha}^{-1}$ of urea $(45 \% \mathrm{~N})$. Irrigation was established on 12/09/2016, 21 days after rice emergence. On 12/15/2016 (36 DAP), $375 \mathrm{~g} \mathrm{ha}^{-1}$ of quinclorac were applied in all the area, including the control plots without Kifix ${ }^{\circledR}$.

The emerged rice seedlings were counted every other day to obtain the emergence curve of the crop up to 25 DAP, in two samples per plot, each sample consisting of two planting rows with $60 \mathrm{~cm}$. Rice plant height was assessed 12 days after emergence, by measuring the distance from the soil surface to the tip of the longest leaf, with a ruler. Ten plants were measured per plot.

The density of jointvetch plants was assessed on 12/19/2016, to quantify the effect of the treatments with Kifix, and again 35 days after quinclorac application, on 01/19/2017. Jointvetch plants present in $4 \mathrm{~m}^{2}$ samples per plot, were counted and cut to soil level, being dried into oven with forced air circulation $65 \pm 5{ }^{\circ} \mathrm{C}$, until constant weight. Also during this period, the general infestation of the area by weeds (composed mostly by jointvetch, with a few individuals of barnyardgrass and other aquatics) was assessed.

Rice grain yield was assessed at the end of the cycle, when two samples of $4 \mathrm{~m}^{2}$ per plot were harvested by hand and threshed, subjected to oven drying with forced air circulation at $45 \pm 5{ }^{\circ} \mathrm{C}$, after which the grains were weighed and their mass corrected to $13 \%$ humidity. The weight of one thousand grains and the weight of grains per panicle were evaluated by collecting five panicles per plot. We also assessed the panicle density and the number of grains per panicle, in two subsamples per plot, each measuring $0.25 \mathrm{~m}^{2}(0.5 \times 0.5 \mathrm{~m})$. At harvest, the weed infestation was assessed again.

We processed the experimental data through descriptive statistics by presenting treatment means with their respective $95 \%$ confidence intervals, according to Cumming et al. (2004). By this method, the comparison between treatments is done based on an expected response interval for similar cropping situations, instead of only on the response of the treatments in the experiment. For rice emergence curve, we fitted a $2^{\text {nd }}$ degree polynomial surface as a function of both days after planting, and dose of Kifix. All analyzes were performed into the statistical environment " $R$ ". 


\section{Results}

The emergence curve evidenced the onset of emergence around five DAP, with stabilization on the number of plants in approximately 200 plants $\mathrm{m}^{-2}, 18 \mathrm{DAP}$ (Figure 1). There was also effect of the herbicide on rice plant establishment, and 20 DAP, about 200 plants $\mathrm{m}^{-2}$ were observed in the control plot, while about 170 plants $\mathrm{m}^{-2}$ were observed under application of $280 \mathrm{~g} \mathrm{ha}^{-1}$ (Figure 1), which represents a potential reduction of approximately $15 \%$ in the establishment of Guri Inta CL plants when the maximum registered dose of Kifix ${ }^{\circledR}$ is applied pre-emergence to rice. It should be noted that although this difference is noticeable, in commercial fields, probably little or no damage would occur to the establishment of the crop plants, since rice is a very plastic plant and stand differences into this magnitude would be easily compensated by tillering (Sousa et al., 1995).

Rice plant height (Figure 2) was stable among treatments. Twelve days after emergence (DAE), plants were between 11-14 cm tall in the control treatment; between 9-13 cm when using the dose of $140 \mathrm{~g} \mathrm{ha}^{-1}$, and between 10-14 $\mathrm{cm}$ for $280 \mathrm{~g} \mathrm{ha}^{-1} \mathrm{Kifix}$, respectively.

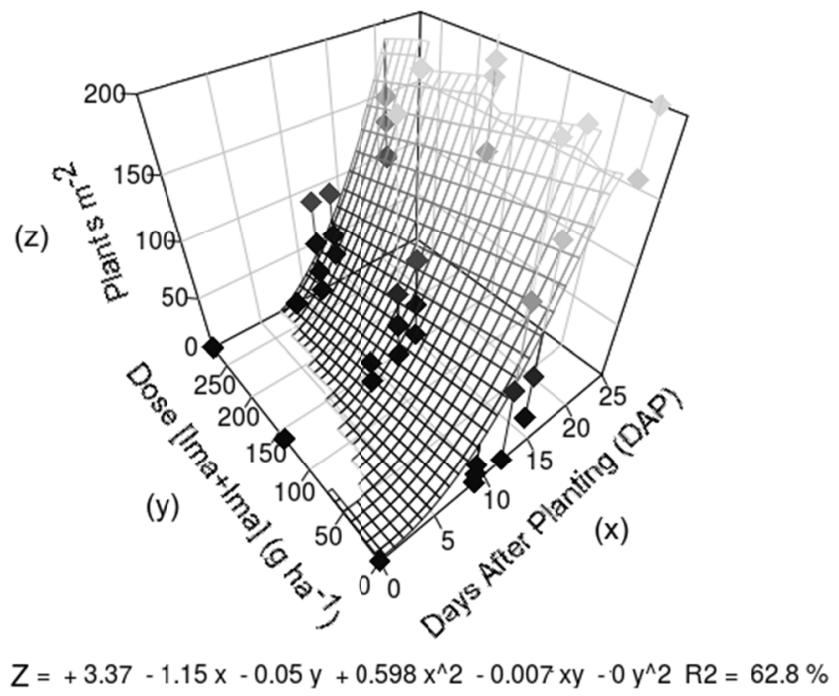

Figure 1. Emergence curve of rice plants cv. Guri Inta CL as a function of days after planting and Kifix ${ }^{\circledR}$ (imazapic + imazapyr) doses

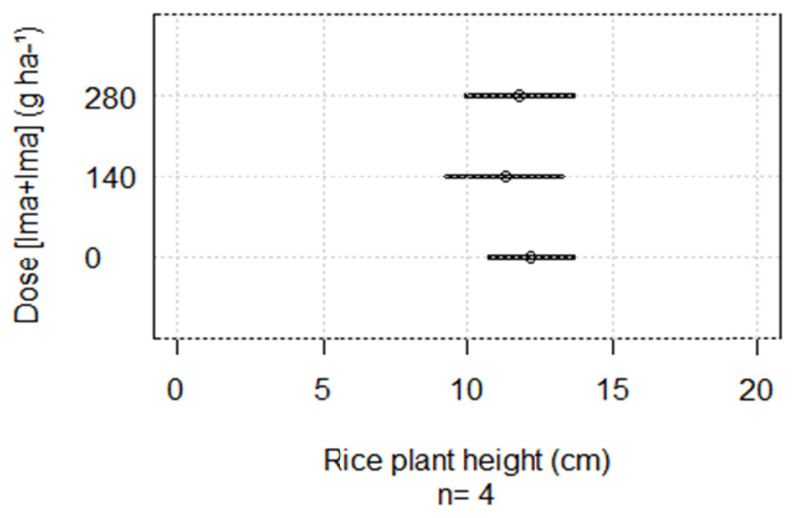

Figure 2. Rice plant height $(\mathrm{cm}) 12$ days after emergence, as a function of Kifix ${ }^{\circledR}$ (imazapic + imazapyr) doses. Confidence intervals at $95 \%$ are presented

Previous studies have shown that although imidazolinone herbicides are highly selective to cultivars with the Clearfield ${ }^{\circledR}$ technology, other rice cultivars planted in the next cropping seasons may be injured by the residues of this herbicide in soil. For the non-tolerant cultivar IRGA 417, the residual effect of [imazethapyr + imazapic] resulted in reduction of plant stand, tiller and panicle density, plant height, sterility and dry mass (Kraemer et al., 
2009). Supposing adverse conditions occur during the crop development, phytotoxicity can lead to reductions in rice grain yield since the crop may not have enough time to recover from the damage caused by the herbicides (Villa et al., 2006).

In another study, Sousa (2010) and Galon et al. (2012) reported increased toxicity to the tolerant cultivar Puitá INTA CL with increasing doses of Only ${ }^{\circledR}$ and Kifix ${ }^{\circledR}$. However, throughout the crop cycle, the variety was able to recover from injuries, with no effect on grain yield. When evaluating the susceptibility of rice, bean and sorghum to Kifix ${ }^{\circledR}$, Xavier et al. (2013) reported high sensitivity of non-clearfield rice cv. BRS Serra Dourada, with no crop emergence at residual doses above $0.9 \mathrm{mg}$ of $\mathrm{Kifix}^{\circledR} \mathrm{dm}^{-3}$ soil.

Although Kifix [imazapic + imazapyr], reported effective on jointvetch (Figure 3), it was not sufficient to control this weed adequately under high infestation conditions (abundant soil seed bank). At 31 DAE, between 22-38 jointvetch plants were observed in the control plot; between 9-28 plants under the usual dose (140 $\left.\mathrm{g} \mathrm{ha}^{-1}\right)$; and between 4-18 plants with the highest dose of [imazapic + imazapyr] (Figure 3). Therefore, even with the application of the maximum dose, the control of jointvetch does not seem to be sufficient in high infestation conditions, demanding additional herbicide application for adequate control of this weed.

With the complementary quinclorac application, the infestation dropped from 22-38 to 4-18 jointvetch plants $\mathrm{m}^{-2}$ in the control treatment, and from 4-18 to 0-6 plants $\mathrm{m}^{-2}$ where the highest dose of [imazapic + imazapyr] was applied (Figure 3). This illustrates that the control of jointvetch when using $375 \mathrm{~g} \mathrm{ha}^{-1}$ of quinclorac, approaches to that obtained with the use of only $280 \mathrm{~g} \mathrm{ha}^{-1}$ of $\mathrm{Kifix}^{\circledR}$ pre-emergence. Accordingly, the jointvetch plants showed also lower dry mass accumulation for about $50 \%$ of the cases (Figure 4) for the treatment with the maximum dose of [imazapic + imazapyr] and complementary application of quinclorac, where every plant weighted 1-4 $\mathrm{g}$. The usual treatment $\left(140 \mathrm{~g} \mathrm{ha}^{-1}\right)$ presented plants with between $2-5 \mathrm{~g}$, being similar to the control plot. The less remarkable difference in jointvetch dry mass, compared to plant density, shows that [imazapic + imazapyr] is efficient pre-emergence of this species, but after emergence, the surviving plants mostly tend not to be inhibited by this herbicide.
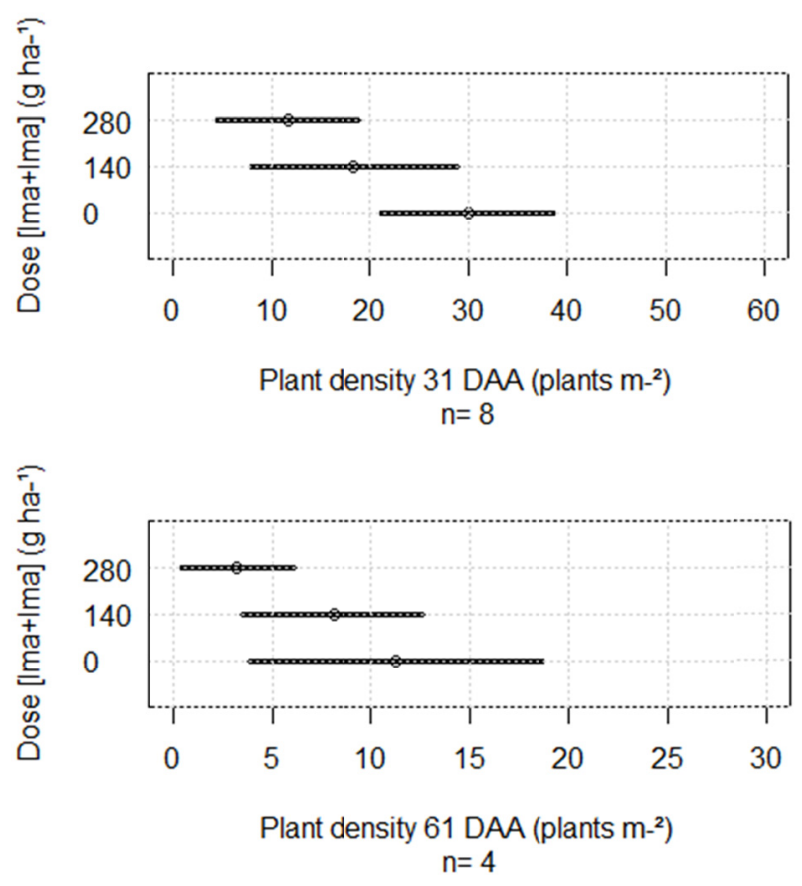

Figure 3. Jointvetch (Aeschynomene spp.) plant density (plants $\mathrm{m}^{-2}$ ) as function of the application of Kifix ${ }^{\circledR}$ (imazapic + imazapyr), complemented or not by quinclorac. Confidence intervals at $95 \%$ are presented

Note. Above: Plant density 31 days after application of Kifix pre-emergence, as function of the treatments; Below: Plant density 62 days after application of Kifix (as function of treatments), and 30 days after the complementary application of quinclorac. 


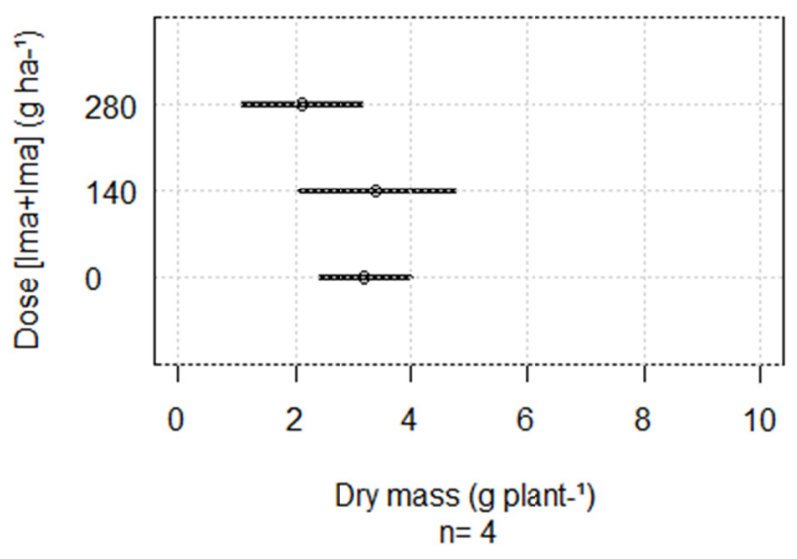

Figure 4. Jointvetch dry mass $\left(\mathrm{g}\right.$ plant $\left.{ }^{-1}\right) 62$ days after crop emergence, as a function of Kifix ${ }^{\circledR}$ (imazapic + imazapyr) doses. Confidence intervals at $95 \%$ are presented

Therefore, under high infestation conditions, control of jointvetch provided by [imazapic + imazapyr] should be complemented with the application of some other effective herbicides such as quinclorac (Fleck et al., 2008).

The overall level of weed infestation (Figure 5) was similar to that observed for jointvetch (Figure 3), as it was the predominant weed in the experiment. The general infestation was between $63-82 \%, 22-60 \%$ and $6-23 \%$, respectively for the control, 140 and $280 \mathrm{~g} \mathrm{ha}^{-1}$ Kifix, respectively (Figure 5). These data suggest that under conditions of low natural infestation, only the application of [imazapic + imazapyr] may be sufficient to adequately inhibit the occurrence of weeds in rice fields with Clearfield ${ }^{\circledR}$ technology. Over time, however, the seed bank of jointvetch in these areas would most likely tend to increase, demanding additional herbicide applications.

This was confirmed when 107 DAE a re-infestation of weeds was observed reaching $92-98 \%, 52-100 \%$ and $14-65 \%$, respectively for the control, 140 or $280 \mathrm{~g} \mathrm{ha}^{-1}$ Kifix. Moments with water levels below the ideal during this period, may have favored the emergence of new weeds since the germination of jointvetch - as for most weeds, is reduced by the water layer (Moraes, 2007). For this species, in particular, germination under a water layer may occur as long as the seeds are on the soil surface (Ferreira, 2007).

In general, imidazolinone herbicides have a long residual effect in soil. Marchesan et al. (2007) reported phytotoxicity and grain yield reduction in non-tolerant rice cultivars grown after two consecutive cultivations with application of [imazethapyr + imazapic]. Monquero et al. (2013) found diclosulam and imazaquin residues 90 days after application, regardless of the soil moisture, while Sousa (2010) detected these herbicides up to 1100 days after application with use of indicator plants. However, the behavior of the imidazolinone herbicides in the environment is variable; the persistence increases with the increase on soil clay and organic matter contents, and reduces with the elevation of pH (Mangels, 1991; Oliveira Jr. et al., 1999; Stougaard et al., 1990; Schreiber et al., 2017). In this sense, the lower clay and organic matter contents in the planosols, can reduce the persistence of the herbicide, especially in aerated soil conditions as in the off-season/winter.

Panicle grain weight was not affected by herbicide application rates, and no substantial difference observed among treatments (Figure 6). 


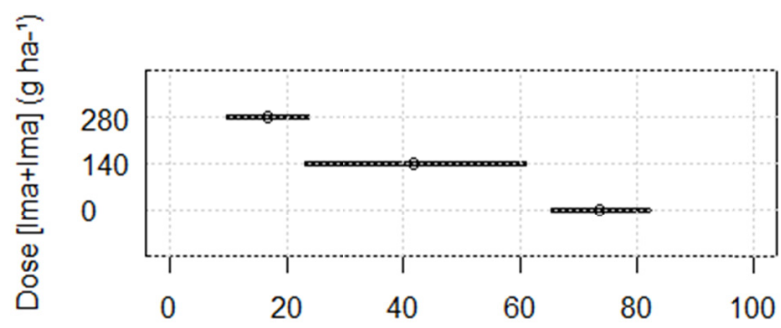

Infestation level of $61 \mathrm{DAE}(\%)$ $n=4$

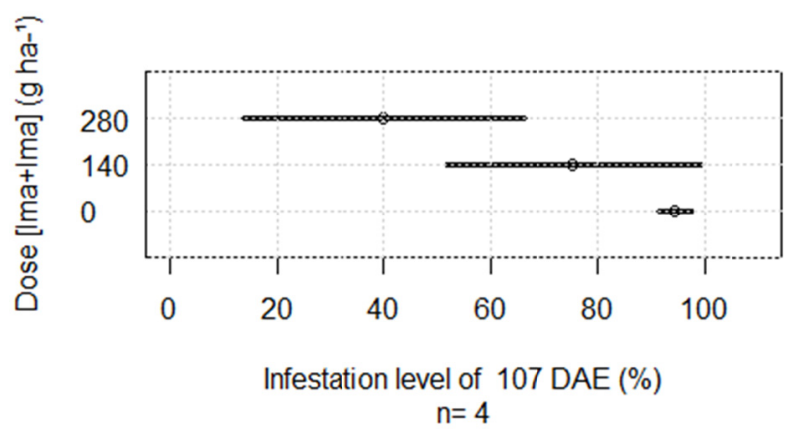

Figure 5. Infestation level of treatments by weed species 61 and 107 days after crop emergence, as a function of Kifix ${ }^{\circledR}$ (imazapic + imazapyr) doses. Confidence intervals at $95 \%$ are presented

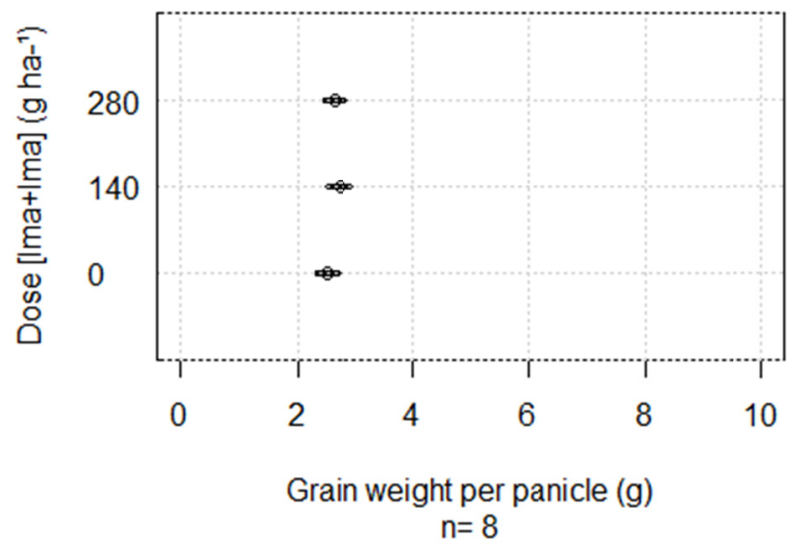

Figura 6. Grain weight per panicle (g) of rice plants at harvest, as a function of Kifix ${ }^{\circledR}$ (imazapic + imazapyr) doses. Confidence intervals at $95 \%$ are presented

The thousand-grain weight varied between 23-25 g, 26-31 g and 25-27 g for control, 140 and $280 \mathrm{~g} \mathrm{ha}^{-1}$, respectively, being higher in herbicide treatments (Figure 7). However, the number of grains per panicle was similar between treatments, ranging between 90-110 (Figure 8). Thus, the application of the different doses of [imazapic + imazapyr] did not affect the number of grains per panicle. 


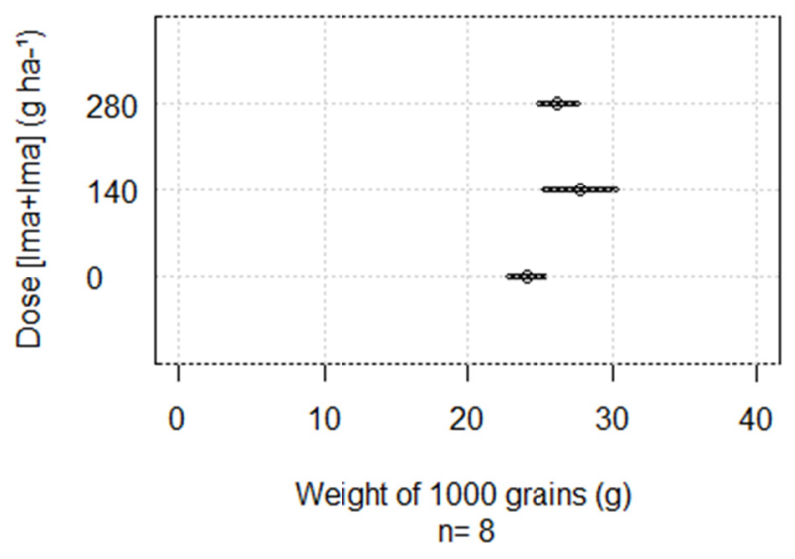

Figura 7. Weight of 1000 grains (g) of rice, as a function of Kifix ${ }^{\circledR}$ (imazapic+imazapyr) doses. Confidence intervals at $95 \%$ are presented

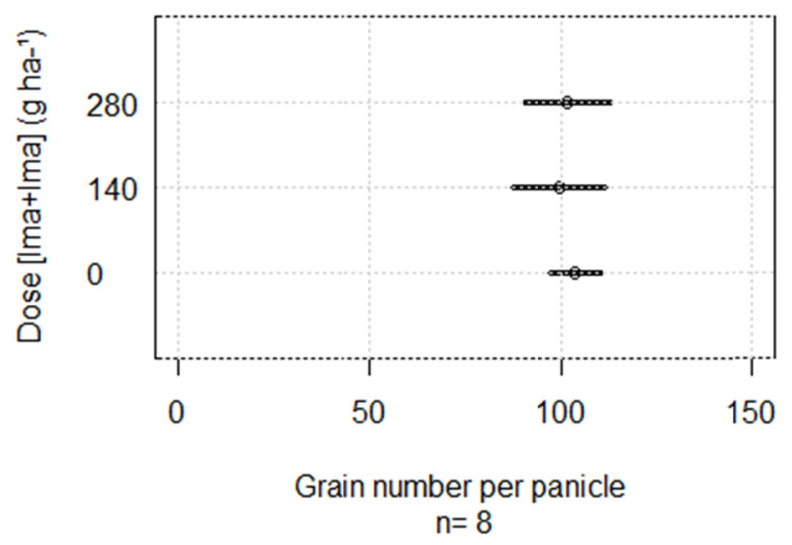

Figura 8. Grain number per panicle of rice, as a function of Kifix ${ }^{\circledR}$ (imazapic+imazapyr) doses. Confidence intervals at $95 \%$ are presented

The panicle density (Figure 9), on the other side, was higher for treatments with [imazapic + imazapyr]. The control presented 160-210 panicles $\mathrm{m}^{-2}$, while 225-260 and 240-300 panicles $\mathrm{m}^{-2}$ were observed for 140 and 280 $\mathrm{g} \mathrm{ha}^{-1}$, respectively. Consequently, the grain yield also showed similarity between herbicide treatments (Figure 10), being around $6200-7300 \mathrm{~kg} \mathrm{ha}^{-1}$, while the control treatment yielded about 4100-5200 kg ha ${ }^{-1}$. These productivity levels are below those normally observed in technologically advanced cropping fields, and were attributed to the high residual infestation by jointvetch (Figure 3), even after application of [imazapic + imazapyr] followed by quinclorac. 


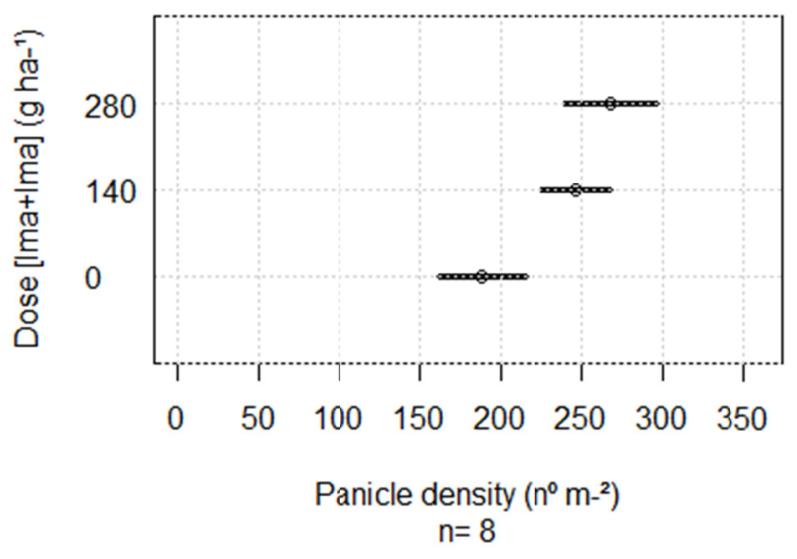

Figure 9. Rice panicle density $\left(\mathrm{n}^{\mathrm{o}} \mathrm{m}^{-2}\right)$ at harvest, as a function of Kifix ${ }^{\circledR}$ (imazapic + imazapyr) doses.

Confidence intervals at $95 \%$ are presented

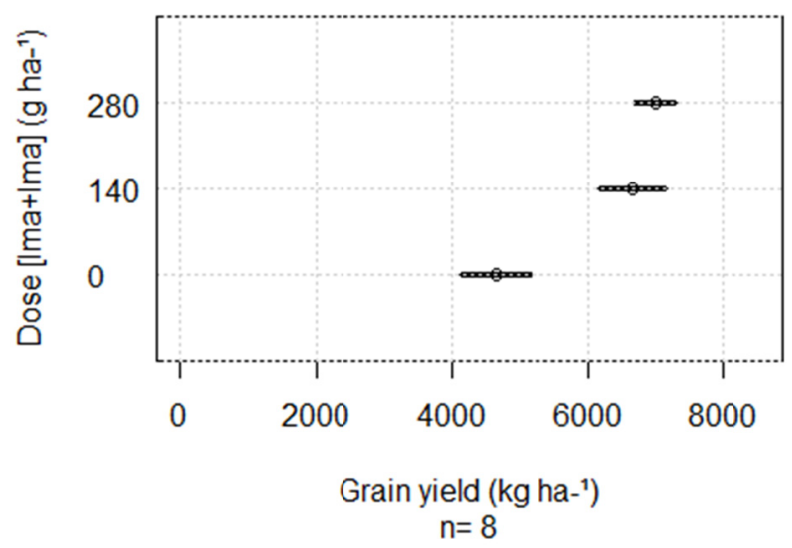

Figure 10. Rice grain yield $\left(\mathrm{kg} \mathrm{ha}^{-1}\right)$, as a function of Kifix ${ }^{\circledR}$ (imazapic + imazapyr) doses. Confidence intervals at $95 \%$ are presented

Therefore, the importance of the jointvetch (Aeschynomene spp.) as a competitor in irrigated rice is highlighted, and other studies should be developed with focus on managing this weed, such as chemical alternatives to avoid that the Clearfield ${ }^{\circledR}$ system is threatened by the difficulty in controlling jointvetch under high infestation and/or deep and continuous water layer. In addition, rice cultivation systems with intermittent irrigation (Toescher et al., 1997; Watanabe et al., 2007; Mezzomo, 2009), which are becoming common in rice plantations in Rio Grande do Sul, can be a case where the Clearfield ${ }^{\circledR}$ technology may not be fully efficient in the control of jointvetch; therefore, in these conditions, an additional herbicide can be required.

\section{Conclusion}

There is a risk of a $15 \%$ reduction in the establishment of Clearfield ${ }^{\mathbb{B}}$ rice plants when the maximum dose of registration of the herbicide [imazapic + imazapyr] is applied pre-emergence; but under appropriate conditions, the crop development tends to compensate for this reduction in establishment. The herbicide [imazapic + imazapyr] is effective on jointvetch, but under high infestation conditions, a complementary herbicide may be required to control jointvetch aiming to guarantee the grain yield levels of the crop.

\section{References}

Agostinetto, D., Fleck, N. G., Rizzardi, M. A., Merotto Junior, A., \& Vidal, R. A. (2001). Arroz vermelho: Ecofisiologia e estratégias de controle. Ciência Rural, 31(2), 341-349. https://doi.org/10.1590/S0103-84782 001000200026 
Agostinetto, D., Galon, L., Moraes, P. V. D., Rigoli, R. P., Tironi, S. P., \& Panozzo, L. E. (2008). Competitividade relativa entre cultivares de arroz irrigado e biótipo de capim-arroz (Echinochloa spp.). Planta Daninha, 26, 757-766. https://doi.org/10.1590/S0100-83582008000400007

Alister, C., \& Kogan, M. (2005). Efficacy of imidazolinone herbicides applied to imidazolinone-resistant maize and their carryover effect on rotational crops. Crop Protection, 24, 375-379. https://oi.org/10.1016/ j.cropro.2004.09.011

Bundt, A. D. C., Avila, L. A., Agostinetto, D., Nohatto, M. A., \& Vargas, H. C. (2015). Carryover of imazethapyr + imazapic on ryegrass and non-tolerant rice as affected by thickness of soil profile. Planta Daninha, 33(2), 357-364. https://doi.org/10.1590/0100-83582015000200022

Ceolin, W. C., Schreiber, F., Andres, A., Concenço, G., Moisinho, I. S., Coradini, M. C., ... Behenck, J. P. (2017). Efeito do herbicida imazapyr+imazapic em diferentes doses no controle de arroz vermelho e capim arroz. Annals of the X Brazilian Rice Congress. Retrieved from http://ainfo.cnptia.embrapa.br/digital/bitstream/ item/164854/1/Germani-Ceolin-EFEITO-DO-HERBICIDA-IMAZAPYRIMAZAPIC-EM-DIFERENTESDOSES-NO-LP.pdf

CONAB (Companhia Nacional de Abastecimento). (2017). Acompanhamento da safra brasileira de grãos-Décimo segundo levantamento-Safra 2015/2016. Retrieved from http://www.conab.gov.br

Cumming, G., Williams, J., \& Fidler, F. (2004). Replication and researchers' understanding of confidence intervals and standard Error Bars. Understanding Statistics, 3(1), 299-311. https://doi.org/10.1207/s1532 8031us0304_5

Dornelles, S. H. B., Garcia, D. C., Loreto, E. L., Canto-Dorow, D. S., Manfron, P. A., Sanchotene, D. M., Oliveira, L. F. V. (2010). Susceptibility of red rice biotypes and commercial rice cultivars to imazethapyr. Planta Daninha, 28, 1097-1106. https://doi.org/10.1590/S0100-83582010000500017

Ferreira, F. B. (2007). Biologia, habilidade competitiva e variabilidade genética em três espécies de angiquinho (Aeschynomene spp.) e seu manejo em arroz irrigado (Unpublished doctoral dissertation, Universidade Federal do Rio Grande do Sul, Porto Alegre, Brazil).

Fleck, N. G., Lazaroto, C. A., Schaedler, C. E., \& Ferreira, F. B. (2008). Suscetibilidade de três espécies de angiquinho (Aeschynomene spp.) a herbicidas de utilização em pós-emergência em arroz irrigado. Revista Brasileira de Agrociência, 14(3-4), 77-86.

Galon, L., Agostinetto, D., Moraes, P. V. D., Tironi, S. P., \& Dal Magro, T. (2007). Estimativa das perdas de produtividade de grãos em cultivares de arroz (Oryza sativa) pela interferência do capim-arroz (Echinochloa spp.). Planta Daninha, 25(4), 697-707. https://doi.org/10.1590/S0100-83582007000400006

Galon, L., Guimarães, S., Burg, G. M., Concenço, G., Rampelotto Filho, A. C., Lima, A. M., \& Belarmino, J. G. (2012). Eficácia e seletividade de herbicidas do grupo das imizadolinonas aplicados em arroz irrigado. Revista Brasileira de Herbicidas, 11(3), 284-295. https://doi.org/10.7824/rbh.v11i3.163

Heap, I. (2017). The International Survey of Herbicide Resistant Weeds. Retrieved from http://www. weedscience.com

Kraemer, A. F., Marchesan, E., Avila, L. A., Machado, S. L. O., Grohs, M., Massoni, P. F. S., \& Sartori, G. M. S. (2009). Persistência dos herbicidas imazethapyr e imazapic em solo de várzea sob diferentes sistemas de manejo. Planta Daninha, 27(3), 581-588. https://doi.org/10.1590/S0100-83582009000300020

Mangels, G. (1991). Behavior of the imidazolinones herbicides in the aquatic environment. In D. L. Shaner, \& S. L. O'conner (Eds.), The imidazolinone herbicides (pp. 183-190). Boca Raton: CRC Press.

Marchesan, E., Teló, G. M., Ferreira, R. B., Massoni, P. F. S., Kraemer, A. F., Machado, S. L. O., \& Avila, L. A. (2007). Residual da mistura formulada dos herbicidas imazethapyr e imazapic em área com cultivo sucessivo de arroz irrigado. Paper presented at the Fifth Brazilian Congress of Irrigated Rice/Twenty-Seventh Meeting of the Irrigated Rice, Pelotas, RS. Retrieved from http:/www.sosbai.com.br/ docs/V_CBAI_Manejo_de_Plantas_Daninhas.pdf

Mezzomo, R. F. (2009). Irrigação contínua e intermitente em arroz irrigado: Uso de água, eficiência agronômica e dissipação de imazethapyr imazapic e fipronil (Unpublished masters thesis, Universidade Federal de Santa Maria, Santa Maria, Brazil). 
Monquero, P. A., Munhoz, W. S., \& Hirata, A. C. S. (2013). Persistência de imazaquim e diclosulam em função da umidade do solo. Revista Agroambiente On-Line, 7(3), 331-337. https://doi.org/10.18227/1982-8470 ragro.v7i3.1311

Moraes, C. L. (2007). Crescimento e desenvolvimento de angiquinho (Aeschynomene spp.) (Unpublished masters dissertation, Universidade Federal de Pelotas, Pelotas, Brazil).

Oliveira, Jr. R. S., Koskinen, W. C., Ferreira, F. A., Khakural, B. R., Mulla, D. J., \& Robert, P. J. (1999). Spatial variability of imazethapyr sorption in soil. Weed Science, 47(2), 243-248.

Pinto, J. J. O., Noldin, J. A., Rosenthal, M. D., Pinho, C. F., Rossi, F., Machado, A., ... Galon, L. (2009). Atividade residual de (imazethapyr + imazapic) sobre azevém anual (Lolium multiflorum), semeado em sucessão ao arroz irrigado, Sistema Clearfield ${ }^{\circledR}$. Planta Daninha, 27(3), 609-619. https://doi.org/10.1590/ S0100-83582009000300023

Schreiber, F., Scherner, A., Massey, J. H., Zanella, R., \& Avila, L. A. (2017). Dissipation of clomazone, imazapyr, and imazapic herbicides in paddy water under two rice flood management regimes. Weed Technology, 31(2), 330-340. https://doi.org/10.1017/wet.2017.5

Sousa, C. P. (2010). Crescimento de plantas de arroz sob aplicação de herbicidas do grupo das imidazolinonas e sua atividade residual em plantas bioindicadoras (Unpublished masters thesis, Universidade Federal de Pelotas, Pelotas, Brazil).

Sousa, R. O., Gomes, A. S., Martins, J. F. S., \& Peña, Y. A. (1995). Densidade de semeadura e espaçamento entre linhas para arroz irrigado no sistema plantio direto. Revista Brasileira de Agrociência, 1(2), 69-74.

Stougaard, R. N., Shea, P. J., \& Martin, A. R. (1990). Effect of soil type and pH on adsorption, mobility and efficacy of imazaquin and imazethapyr. Weed Science, 36(1), 67-73.

Toescher, C. F., Righes, A. A., \& Carlesso, R. (1997). Volume de água aplicada e produtividade do arroz sob diferentes métodos de irrigação. Revista da FZVA, 4(1), 49-57.

Vargas, R. (2017). Herbicide resistance. Retrieved from http://ag.arizona.edu/crops/pesticides/papers/ herbresis.html

Villa, S. C. C., Marchezan, E., Avila, L. A., Massoni, P. F. S., Telo, G. M., Machado, S. L. O., \& Camargo, E. R. (2006). Arroz tolerante a imidazolinonas: Controle do arroz-vermelho, fluxo gênico e efeito residual do herbicida em culturas sucessoras não tolerantes. Planta Daninha, 24(4), 761-768. https://doi.org/10.1590/ S0100-83582006000400017

Xavier, A. N., Godoi, W. M., Coleta, R. F., \& Lacerda, M. C. (2013). Efeito residual do herbicida Kifix ${ }^{\circledR}$ nas culturas de arroz, feijão e sorgo. Paper presented at the Seventh Young Talent Seminar, Santo Antônio de Goiás, GO. Retrieved from https://ainfo.cnptia.embrapa.br/digital/bitstream/item/100947/1/p19.pdf

Watanabe, H., Nguyen, M. H. T., Souphasay, K., Vu, S. H., Phong, T. K., Tournebize, J., \& Ishihara, S. (2007). Effect of water management practice on pesticide behavior in paddy water. Agricultural Water Management, 88(1-3), 132-140. https://doi.org/10.1016/j.agwat.2006.10.009

\section{Copyrights}

Copyright for this article is retained by the author(s), with first publication rights granted to the journal.

This is an open-access article distributed under the terms and conditions of the Creative Commons Attribution license (http://creativecommons.org/licenses/by/4.0/). 